\title{
Kajian Historis Tentang Gamelan Ketug Bumi
}

\author{
Hendra Santosa \\ Program Studi Seni Karawitan, Fakultas Seni Pertunjukan, \\ Institut Seni Idonesia Denpasar \\ hendrasnts@gmail.com
}

Gamelan Ketug Bumi merupakan gamelan baru yang lahir pada tahun 2015 atas prakarsa I Gede Arya Sugiartha yang telah berkembang sedemikian rupa. Sebagai gamelan baru, tentulah belum banyak orang yang menuliskannya dalam berbagai kajian baik seni, musikologi, maupun kajian lainnya. Oleh karenanya penulis mencoba untuk menulisnya dalam sebuah kajian historis. Tulisan ini bertujuan untuk mengungkapkan dan menegaskan bahwa dalam setiap peristiwa yang terjadi pada saat sekarang adalah sebuah rangkaian dari peristiwa-peristiwa masa lampau, seperti halnya gamelan Ketug Bumi yang dapat diurut pekembangan dan perubahannya dari peristiwa masa lampau. Penelitian ini menggunakan metode sejarah yaitu berupa heuristik, kritik, interpretasi, dan historiografi. Heuristik dilakukan terhadap dokumen masa kini berupa Surat Keputusan Staf Produksi Pawai Ketug Bumi tahun 2015, kemudian dari dokumen masa lampau berupa kakawin dan babad. Instrumen utama yang dipergunakan dalam gamelan Ketug Bumi yaitu tambur (mredangga), dipergunakan sebagai unsur utama dalam penelusuran kesejarahan gamelan Ketug Bumi. Penjelasan mengenai mredangga sebagian telah penulis terangkan dalam artikel yang berjudul "Mrědangga: Sebuah Penelusuran Awal Tentang Gamelan Perang di Bali" pada jurnal Kalangwan. Kata tambur sendiri penulis temukan dalam naskah kesusastraan Bali yang berjenis parikan, tetapi banyak ditemukan pada naskah yang berbentuk babad dari luar Bali.

Kata kunci: gamelan, ketug bumi, tambur, mredangga, sejarah

\section{Historical Study of Gamelan Ketug Bumi}

Gamelan Ketug Bumi is a new gamelan that was born in 2015 on the initiative of I Gede Arya Sugiartha which has developed in such a way. As a new gamelan, there are certainly not many people who have written it in various studies, including art, musicology, and other studies. Therefore the author tries to write it in a historical study. This paper aims to express and emphasize that in every event that occurs at this time is a series of past events, such as the Ketug Bumi gamelan which can be sequenced in its development and changes from past events. This study uses the historical method in the form of heuristics, criticism, interpretation, and historiography. Heuristics are carried out on current documents in the form of 2015 Ketug Bumi Parade Production Staff Decree, then from past documents such as kakawin and babad. The main instrument used in the Ketug Bumi gamelan is tambur (mredangga), used as the main element in the historical search of the Ketug Bumi gamelan. The writer explained in part about the mredangga in an article entitled "Mrĕdangga: An Early Search of the Gamelan War in Bali" in the journal Kalangwan. The word tambur itself is found in the Balinese literary manuscript of the parikan type, but many are found in manuscripts in the form of babad from outside Bali.

Keyword: gamelan, ketug bumi, tambur, mredangga, sejarah

Proses Review : 7 - 25 Januari 2019, Dinyatakan Lolos: 29 Januari 2019 


\section{PENDAHULUAN}

Pada saat acara Pesta Kesenian Bali (PKB) pada 2015, ISI Denpasar menjadikan tambur sebagai instrumen utama dalam gamelan Ketug Bumi. Tambur pada saat ini masih banyak dipergunakan untuk upacara-upacara keagamaan di Bali. Dalam olah kreativitas kesenian juga dijadikan salah satu instrumen dalam gamelan Adi Merdangga, atau juga gamelan Tambur di Karangasem. Tambur atau Genderang (kendang) diartikan sebagai alat bunyi-bunyian berupa kayu bulat panjang di dalamnya berongga dan pada salah satu lobang atau kedua-duanya diberi kulit (Lukman, 1996: 308) atau juga dapat disebut dengan bedug. Ada dua macam bedug yang saat ini berkembang, yaitu bedug dengan satu membran dan bedug dengan dua membran. Instrumen bedug saat ini masih dipergunakan di Bali, seperti gamelan Gong Beri. Kata bedug sendiri ada dalam karya sastra Kidung Malat. Pada beberapa karya sastra lainnya instrumen besar bermembran ini ada yang disebut dengan teteg atau keteg. Di Bali sendiri diibaratkan bahwa bunyi teteg disuarakan dengan suara kulkul, kiranya hal ini dapat dijadikan penelitian tersendiri. Dalam beberapa naskah kuno yang lebih muda, kata mrdangga sudah hilang dan berganti dengan tambur (Santosa, 2018: ). Tambur mirip dengan kendang Bali tetapi bentuknya lebih besar, dan ukurannya sama dengan kendang Beleq di Lombok. Perlu diketahui bahwa Lombok pada masa lampau pernah menjadi daerah bawahan kerajaan Karangasem. Saat ini pulau Lombok di samping dihuni oleh suku Sasak, juga dihuni oleh penduduk yang bersuku Bali. Pada saat ini instrumen Tambur telah membentuk jenis kesenian baru yaitu Kendang Beleq. Jenis kesenian ini mirip dengan gamelan Balaganjur hanya kendangnya saja yang berbeda yaitu menggunakan kendang besar seperti halnya tambur. Tambur pada saat ini masih banyak dipergunakan untuk upacara-upacara keagamaan di Bali. Dalam olah kreativitas kesenian juga dijadikan salah satu instrumen dalam gamelan Adi Merdangga, atau juga gamelan Tambur dari daerah Karangasem, terakhir pada saat acara Pesta Kesenian Bali (PKB) pada 2015, ISI Denpasar menjadikan tambur sebagai instrumen utama dalam gamelan Ketug Bumi. Namun yang sangat menarik bahwa sampai saat penulisan artikel ini, kata tambur baru satu saja yang penulis temukan yaitu dalam karya sastra Malat Parikan, sedangkan dalam karya kesusastraan Bali yang bergenre babad belum penulis temukan. Kata tambur sendiri banyak penulis temukan dalam kesusastraan dari luar Bali yaitu dari Jawa dan Lombok.

Curt Sachs mengungkapkan bahwa tambur (tambour) adalah alat musik dari Prancis (Sachs, 1940: 78). Seperti telah dijelaskan bahwa di Bali juga terdapat instrumen Tambur dan masih bertahan dibeber- apa daerah seperti di daerah Karangasem. Oleh karenanya buku ini sangat penting karena menyangkut tentang penyebaran drum (kendang) diseluruh dunia serta menyangkut pula tentang fungsi instrumennya. Selanjutnya masih dalam buku yang sama dijelaskan tentang berbagai instrumen yang termasuk dalam golongan membranophones mulai dari bahan yang digunakan, bentuk, sistem pengancingan kulit, posisi pemain, dan cara memainkannya (Sachs, 1940: 459-463). Kendang besar seperti ini terdapat dalam gamelan Gong Bheri yang disebut dengan Bedug. Seperti yang diuraikan Kunst bahwa ketika Belanda pertama kali mencapai Jawa di 1596, bedug tersebar luas dan populer, sebuah kutipan dari "D'Eerste Boeck" halaman 107, merujuk pada kota Banten (Kunst, 1968: 43-44). Pada saat ini Bedug dipergunakan di masjid-masjid, mushola, dan langgar-langgar untuk memberitahukan kepada masyarakat di sekitarnya bahwa telah memasuki waktu sholat.

\section{METODE PENELITIAN}

Sejarah gamelan Bali sebagai peristiwa yang berkelanjutan dan membentang dalam waktu yang sangat panjang tentunya dengan perubahannya pula. Peristiwa sejarah yang melingkupi gamelan Bali tidak terlepas dari kreativitas dan kualitas manusia Bali. Peristiwa-peristiwa sejarah yang melibatkan gamelan telah terjadi dan meninggalkan jejak-jejak yang dapat dijadikan sumber untuk penelusuran kembali tentang bagaimana sesungguhnya peristiwa yang melibatkan gamelan itu terjadi. Untuk memenuhi standar keilmuan, sebuah cerita peristiwa sejarah diperlukan prosedur dan proses tertentu yang disebut metode sejarah. Jika metode sejarah dilalui dengan benar dalam penyusunan kembali (rekonstruksi) sesuatu peristiwa sejarah, maka kisah yang dihasilkan akan obyektif dan mendekati peristiwa yang sebenarnya. Dengan menggunakan metode sejarah maka cerita mengenai gamelan Ketug Bumi dapat disusun secara sistematis, analitis, dan kronologis berdasarkan urutan waktu kejadian.

Metode sejarah adalah proses menguji dan menganalisis secara kritis rekaman dan peninggalan masa lampau. Metode sejarah terdiri dari heuristik, kritik, interpretasi, dan historiografi, dengan tujuan merekonstruksi masa lalu (Garraghan, 1957: 33-69). Untuk menempuh prosedur yang benar dalam penelitian sejarah diperlukan tahapan yang runut. Tahap pertama adalah heuristik merupakan langkah awal penelitian dimulai dari mengumpulkan berbagi sumber data yang terkait dengan masalah yang sedang diteliti, yaitu sumber tertulis, sumber lisan, sumber benda atau artefak (Gootchlak, 1975: 35-36; Herlina, 2014: 7; Kuntowijoyo, 2003: 94-95). Sumber-sumber tertulis kontemporer yang dikumpulkan berupa 


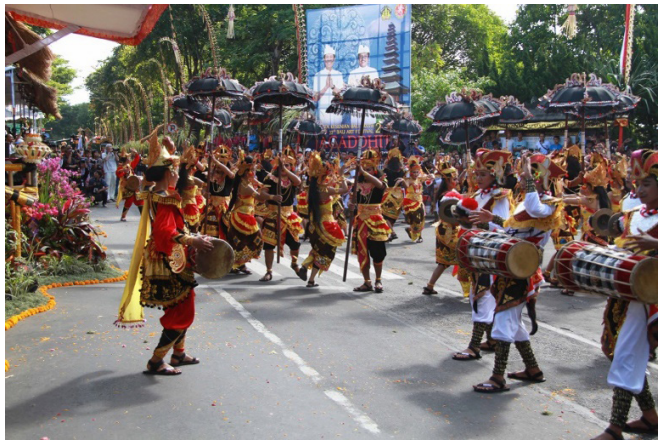

Gambar 1. Pertunjukan Ketug Bumi Pada 2015 (Sumber: Koleksi Unit Kearsipan ISI Denpasar pada 2015)

surat keputusan tentang pawai gamelan Ketug Bumi tahun 2015. Kemudian merujuk dari instrumen yang dipergunakan dalam surat keputusan tersebut maka ditelusurilah penggunaan kata tambur dan ketug dalam berbagai karya kesusastraan baik yang berbentuk kakawin dan babad. Selanjutnya kritik atau analisis merupakan pengujian terhadap keaslian sumber dan pengujian kredibilitas sumber atau yang disebut dengan kritik internal. Melalui kritik dihasilkan sumber otentik yang teruji dan dapat dipercaya. Ketiga dilakukan interpretasi atau penafsiran terhadap fakta dan sumber sejarah, dan terakhir adalah historiografi penuangan dalam bentuk tulisan berupa laporan dalam bentuk penulisan multidimensional.

\section{ANALISIS DAN INTERPRETASI DATA}

Kata ketug bumi terdapat dalam lontar Prakempa pada syair 69 yang berbunyi: Gendingnya yan babonangan ketug bhumi ngaran. Artinya: Nyanyian babonangan ketug bhumi namanya (Bandem, 1986: 87). Lontar Aji Gurnita disebutkan pula tentang kata ketug bhumi dengan bunyi sebagai berikut.

Gendingnya, yan babonangan, ngaran ketug bhumi, yan gong nga, Ora akaça. Kunang katatwanya babonangan, ika, tiru maring dasar bumi, rikala nikang wataking bhuta kala apupul, adeng mangkana pinalu gagambĕlan babonangan ika, gumeter rasaning bhuwana donya dadya anggawe resrsing manah kadya gempura saking pretiwi, dening swaran babonangan ika, maka gagambělaning pamahayu sanjata, salwiring barbar sang prabhu mwang açarawan sanjata, ring lebuh agung (Aryasa, 1976: 79).

Artinya:

Gendingnya bebonangan dinamai: ketug bhumi, debaran bumi. Kalau suara yang dinamai Ora akaça, angkasa lengkap. Adapun riwayatnya bebonangan itu, meniru dasar bumi, tatkala sebangsa butakala berkumpul pada saat itu dipukul bunyi-bunyian bebonangan itu, gemetar perasaan dunia olehnya, membuat khawatir pikiran, seakan-akan akan digempur

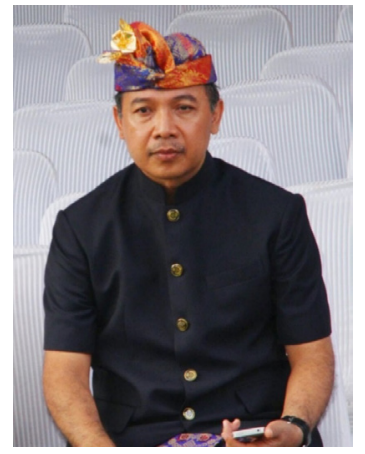

Gambar 2. I Gede Arya Sugiartha Penggagas Ketug Bumi, 2015

(Sumber: Koleksi Unit Kearsipan ISI Denpasar 2015)

dari dalam bumi, itulah sebabnya suara bebonangan itu dipakai mengupacarai senjata segala perlengkapan raja dan pada waktu melatih barisan senjata di jalan raya (Aryasa, 1976: 93).

Melihat keterangan di atas dapat ditarik simpulan bahwa kata ketug bumi adalah nama gending pada gamelan bebonangan yang dipergunakan untuk mengupacarai senjata dan latihan pasukan bersenjata di jalan raya. Kemudian jika kita perhatikan dengan munculnya gamelan Ketug Bumi pada 2015, maka telah terjadi transformasi dari nama gending bebonangan menjadi nama gamelan. Berdasarkan data dokumen yang penulis miliki terdapat pertentangan data antara data lokal Bali (Prakempa dan Aji Ghurnita), dengan foto-foto yang dihasilkan para peneliti Belanda dan Juga peneliti Amerika, sekiranya hal ini akan penulis bahas dalam artikel yang akan datang.

Proses Penciptaan Seni Pertunjukan Ketug Bumi Berdasarkan wawancara dengan Prof. I Gede Arya Sugiarta selaku Rektor ISI Denpasar, yang merupakan penggagas dari gamelan Ketug Bumi pada 24 Januari 2017 jam 11.30, Prof. Arya mengungkapkan bahwa beliau melihat perkembangan Adhi Merdangga dari 1984 (30 tahun) telah berkembang dan telah menyebar di seluruh Bali, ketika semua kabupaten di Bali pada setiap pawai PKB kabupaten sudah menggunakan Adhi Merdangga. Kemudian sanggar-sanggar seni pertunjukan di Bali juga sudah biasa mempertunjukan gamelan Adhi Merdangga. Kemunculan gamelan Ketug Bumi tidaklah untuk memberhentikan Adhi Merdangga tetapi dikarenakan lebih didorong oleh suatu keinginan untuk berkreativitas untuk meciptakan sesuatu yang baru.

Dimulai dengan mengundang seluruh dosen karawitan berembug untuk menciptakan sebuah musik prosesi yang besar yang cocok dipertunjukan pada pawai pembukaan untuk mengiringi simbol PKB yaitu Siwanataraja. Teman-teman dosen karawitan mengusulkan untuk fokus pada alat-alat yang berat 


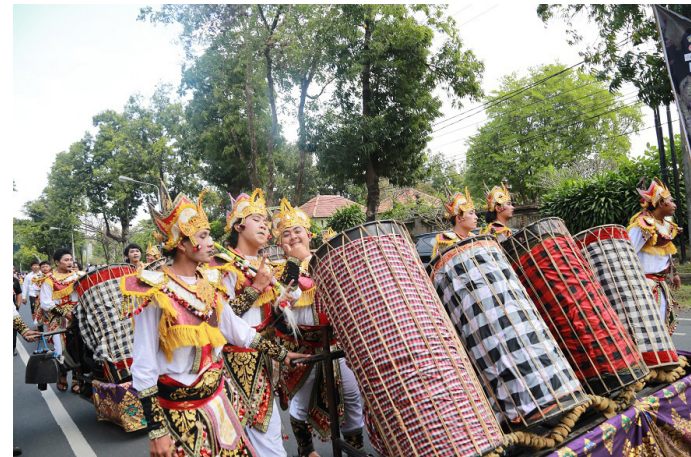

Gambar 3. Tambur Dalam Pertunjukan Ketug Bumi 2018

(Sumber: Koleksi Unit Kearsipan ISI Denpasar 2018) dan besar. Instrumen utama Adhi Merdangga mempergunakan beragam kendang Bali, pada gamelan Ketug Bumi menggunakan instrumen utamanya adalah bedug atau tambur, cengcengnya diperbesar dari yang biasa, untuk melodi menggunakan instrumen tawa-tawa dibuat bernada, kentongan, dan okokan. Untuk membawa instrumennya terutama gong, bedug atau tambur dipergunakan alat atau tempat yang bisa didorong. Kemudian dilakukan percobaan-percobaan dan memang suaranya menggelegar dan menggetarkan, bunyinya berbeda dengan Adhi Merdangga. Jadi gamelan Ketug bumi ini lebih mengarah pada instrumen yang mempunyai karakter berat. Seperti telah dijelaskan di atas, nama Ketug Bumi didapat dari lontar prakempa dan lontar Aji Gurnita bagian catur muni-muni. Nama Ketug Bumi juga sesuai dengan bunyi yang dihasilkan pada saat percobaan-percobaan karena bunyinya menggelegar (Sugiartha, 24 Januari 2017).

Seolah-olah sudah menjadi jembantan penghubung antara gamelan Ketug Bumi dan Siwanataraja, karena filosofi dari tari Siwanataraja itu adalah Siwa sebagai dewa tertinggi yang membuat keteraturan dunia dengan cara menari, ketika menari itu, dunia diputar oleh Siwa, kenapa diputar, karena dengan diputarnya dunia, akan muncul keteraturan, karena sebelum diputar dunia oleh Siwa, dunia itu banyak terjadi kekacauan, tidak harmonis karena dunia tidak berputar, ketika berputar terciptalah lima alam ini yang membuat harmonis karena ada siang malam. Artinya siklus perputaran membawa keteraturan dan keharmonisan. Maka cocoklah nama gamelannya Ketug Bumi, berbunyi ketika dunia berputar, dan tariannya Siwanataraja, karena Siwa memutar dunia, lebih cocok dan bersambung sebenarnya. Sebagai penggarap komposisi diberikan pada komposer muda I Wayan Sudirana, Phd untuk menafsirkan bagaimana ide awal dan tema ini dapat digarap menjadi sebuah seni pertunjukan yang bersifat prosesi (Sugiartha, 24 Januari 2017).

I Wayan Sudirana sebagai komposer pertama gamelan Ketug Bumi mempunyai penafsiran bahwa Ketug Bumi/Gumi, sesuai artinya (ketug: bergetar, Bumi: jagat raya), ditafsirkan sebagai ensambel besar yang mampu menggetarkan semesta. Alat musik yang dipakai cenderung besar dan/atau bersuara mengelegar, seperti bedug/tambur, cengceng besar, kendang, kulkul (kentongan), okokan, digabungkan degan instrumentasi balaganjur dan alat musik afrika seperti jimbe. Gending yang dihasilkan diharapkan bisa menggetarkan sanubari setiap pendengar.

Hal tersebut dituangkan dalam proses penciptaan gending melalui tahap eksplorasi yang dilakukan berupa pengumpulan instrumen, pencarian warna suara dan melakukan pengelompokan instrumen sesuai kebutuhan garap, kemungkinan konsep musikal yang sesuai dengan materi, konsep, dan eksplorasi formasi barisan. Kemudian pada tahap improvisasi yang dilakukan berupa pengolahan unsur-unsur yang disebutkan pada ide dan tema awal gamelan Ketug Bumi untuk mengiringi tarian Siwanataraja.

Selanjutnya Sudirana membuat catatan/notasi untuk ketepatan musikal yang diinginkannya. Dalam gending Ketug Bumi, dipergunakan banyak poliritme dan polimeter untuk menggarap melodi dan menggarap ritmisnya. Selanjutnya pembentukan dilakukan sesuai dengan proses pembentukan gending pada gamelan pada umumnya, penuangan juga dilakukan dengan sistem oral yaitu membunyikan apa yang dimaksud dan dilakukan pengulangan oleh para penabuh. Penabuh mengalami kesulitan pada awal proses karena banyak motif baru yang dipakai. Pemberian pemahaman musikal terkait ide garap sering dilakukan pada awal latihan sebelum penuangan gending. Singkronisasi dengan penari dilakukan karena banyaknya elemen musik baru yang dipergunakan, penari/penggarap tari harus terlebih dahulu meninggalkan atau melepaskan ekspektasi musik sebagai iringan yang sudah biasa/mentradisi dengan membuka pikiran dengan asupan "rasa" baru yang belum pernah mereka dengar/rasakan sebelumnya. Penggarap tari secara khusus dilatih untuk memahami elemen musikal (terutama pembagian ketukan dan aksen) supaya hasil gerak tari bisa harmonis dengan musik.

\section{Instrumentasi Gamelan Ketug Bumi}

Keputusan rektor Institut Seni Indonesia (ISI) Denpasar nomor 1534/IT5.5.2/LL/2015 tentang pembentukan staf produksi pawai Ketug Bumi Pesta Kesenian Bali (PKB) XXXVII pada 2015 yang bertanggal 25 Mei 2015 yang terdiri dari 14 lembar termasuk di dalamnya memuat tiga lampiran. Lampiran 1 memuat staf produksi, lampiran dua tentang susunan penari dan penabuh pawai Ketug Bumi, dan lampiran tiga tentang susunan staf produksi tari Pendet. Pada lampiran satu tercatat bahwa staf produksi pawai Ketug Bumi berjumlah 95 orang dengan penanggung 
jawab Prof. Gede Arya Sugiartha, SSKar., M.Hum., kemudian tercatat bahwa para penata dipercayakan pada komposer dan koreografer muda, seperti untuk penata karawitan Dr. I Wayan Sudirana, S.Sn., MA., bersama I Wayan Diana Putra, S.Sn., M.Sn., dengan penata tari atau koreografer dipegang oleh Ida Ayu Arya Satyani, S.Sn., M.Sn., I Wayan Adi Gunarta, S.Sn., M.Sn., Ni Made Liza Anggara Dewi, S.Sn., M.Sn., I Gede Gunadi Putra, S.Sn., M.Sn., dan Ni Made Haryati, S.Sn., M.Sn (Lampiran 1 SK Rektor ISI Denpasar nomor 1534/IT5.5.2/LL/2015).

Pada lampiran dua tercatat tentang susunan penari dan penabuh pawai Ketug Bumi dalam rangka Pesta Kesenian Bali (PKB) XXXVII pada 2015 yang mengungkapkan nama-nama dan dan perannya masing-masing dalam kegiatan pawai Ketug Bumi. Kelompok Tari tercatat 50 orang yang terdiri dari 31 orang penari, satu orang pembawa papan nama dan 18 orang perias. Kemudian pada kelompok penabuh sebanyak 102 orang. Peran masing-masing juga tercatatkan antara lain penabuh jimbe sebanyak 10 orang, tawe-tawe/suling (kemungkinan besar instrumen tawa-tawa) 9 orang, tawe-tawe (kajar) satu orang, reyong 6 orang, cengceng 15 orang, kendang 22 orang, kendang bedug 8 orang, okokan 10 orang, sungu 10 orang, gong kempul bende (kemungkinan gong, kempur, dan bebende) dua orang, dan tukang tegen (tukang pikul) 8 orang (Lampiran 2 SK Rektor ISI Denpasar nomor 1534/IT5.5.2/LL/2015). Berdasarkan peran penabuh, dapat disimpulkan bahwa instrumentasinya terdiri dari jimbe (damaru), tawa-tawa yang dibuat bermelodi dan suling, tawa-tawa yang berfungsi sebagai kajar, reyong, cengceng, kendang Bali, bedug, okokan, sungu, gong, kempur, dan bebende.

\section{Tambur dalam Babad}

Kata Tambur tersurat dalam beberapa karya kesusastraan baik di Jawa, Bali, maupun di Lombok, tetapi dalam karya kesusastraan yang tergolong muda misalnya kesusastraan Malat Parikan, Babad Majapahit, dan Babad Madura. Berikut penulis sampaikan pupuh-pupuh yang mengandung kata tambur dalam Malat Parikan tercatat dalam Pupuh Pangkur No. 55 yang berbunyi: Saha tambur gong masuara. ngalik-alik munyine manempengin, bilang magisi matabuh, sami ilang makasukan, (Bagus, 1982: 138). Artinya: Beserta tambur dan gong lalu dibunyikan. suarasnya gemuruh memekakkan telinga, dibunyikan terus, semua bersemangat. (Bagus, 1982: 73).

Selanjutnya dalam pupuh Durma Nomor 4, yang berbunyi: Saha tambur gong mamunyi nggilakang. Pagisi hu mati. Becek kaprajaya. api murub mangabar, galang dumuah nikelin. panunggu petak. sisan puun mudiding (Bagus, 1982: 141). Artinya: Tambur serta gong ber- bunyi dengan ramainya, banyak yang mati dihancurkan oleh musuh, api berkobar-kobar. amat terang-benderang, penjaga benteng, sisa yang terbakar, lari terbirit-birit (Bagus, 1982: 76). Pada pupuh nomor 8, tambur dipergunakan untuk penghormatan dan berbunyi seperti berikut. watek Mantri sama. ngiring Sri Rantajaya pamit mijil lan Sang Panji lan Raden Senetan, tambur ngrudug manghing. (Bagus, 1982: 150). Artinya: para menteri semua, mengikuti Sri Rantanaja, permisi keluar bersama Raden Panji, serta Raden Senetan, diiringi suara tambur yang gemuruh, (Bagus, 1982: 77). Kemudian pada pupuh nomor 69 berbunyi: Mairingan tambur tanda, gong bendene mangempingin, ngrudug masuara. Teken sungu makilit (Bagus, 1982: 150). Artinya: Diiringi oleh suara gendrang. suara gong dan bebende memekakkan telinga, suaranya gemuruh, juga disertai suara terompet yang bersaut-sautan (Bagus, 1982: 85). Pada pupuh 55 tambur dipergunakan untuk memberikan semangat pada prajurit yang sedang berperang. Kemudian pada pupuh durma 4, tambur dipergunakan untuk mengiringi peperangan. Pada pupuh 8 , tambur dipergunakan untuk mengiringi Sri Rantanaja bersama rombongan untuk keluar balairung. Pada pupuh 69, tambur dipergunakan untuk upacara penyambutan. Kata tambur dalam babad Majapahit Jilid I yang berjudul Kencana Wungu Naik Tahta, milik perpustakaan Nasional RI terdapat dalam pupuh IV 24, Pupuh V (Mijil) halaman 49. No 18, Pupuh IX (Dangdanggula) no. 10 halaman 64, XV Pupuh Dangdanggula no 14 halaman 87, V Pupuh Mijil No. 18 halaman 49, dan terjemahannya Halaman 188. Pupuh IV (Durma) nomor 24 disebutkan bahwa: Sigra bendhe tengara barung ghurnita, Syaranira melingi, Teteg wantya wantya, Tambur munya brang brangan, Salumpret pating jalerit, Syara gumentar, Gya budhal punang baris (Irawan, 2008: 44). Artinya: Segera membunyikan tengara bersama-sama dan suaranya gemuruh terus menerus. Tambur berbunyi ramai dan terompet suaranya melengking. Pasukannya segera berangkat(Irawan, 2008: 128).

Pada pupuh V (Mijil) nomor 18 berbunyi: Kenthung saruni tinitir titir, Barung gong mabegor, Bendhe ngungkung brang brangan tambure, Barung umwang salumpret ting jalerit, Wor swaraning jalmi Lir bantu kumerut (Irawan, 2008: 49). Artinya: Kentongan bertalu-talu dan seruling berbunyi bersama gong. Suara bende bertalu-talu bersama suara tambur. Terdengar dengan suara seruling yang menjerit bersama suara manusia seperti menambah ramai (Irawan, 2008: 188). Pada pupuh IX (Dangdanggula) nomor 10 berbunyi: Injing gumentar swarane, Tengara umyang gumruh, Kang kendang gong tambur myang bheri, Salumpret munya ngraras, keketeg lir ketug, Sumahab kang wadyabala, Kyadipati menak rongga myang ngabehi, Aglar aneng paseban ( Irawan, 2008: 64). Artinya: Pagi hari terdengar suara 
ramai. Tenggara berbunyi gemuruh, gendhang, gong, tambur, dan terompet, suaranya bertalu-talu seperti geledeg. Semua pasukan sudah bersiap. Para adipati, menak, rangga, dan ngabehi sudah berada di paseban (Irawan, 2008: 205).

Pada pupuh XV Dangdanggula nomor 14 berbunyi: Slumpret kenthung bherinya tinitir, Wadya kinen asurak sedaya, Teka dadi pepantese, Saweneh para ratu, Beksa gendhing acara bali, Weneh kala gumentar, Ana slumpret tambur, Saweneh rebab biyola, Saksukane sakwusnya akambel bukti, Nginum sami prasetya ( Irawan, 2008: 87).

\section{Artinya:}

Terompet, kentongan, dan kendang dipukul bertalu-talu. Para prajurit disuruh bersorak semuanya menjadi sangat ramai. Para raja yang lain menari dengan iringan gamelan. Banyak suara musik yang berbunyi. Ada terompet dan kendang, ada juga rebab dan biola. Setelah bersenang-senang lalu makan dan minum bersama ( Irawan, 2008: 230).

Kata Tambur juga terdapat dalam Babad Madura, koleksi Perpustakaan Nasional RI dan Balai Pustaka yang dikerjakan oleh Sastronaryatmo, Mulyono dan Indri Nitriyani, pada 1981, terdapat dalam pupuh VIII sinom nomor 17 halaman 72 yang menyebutkan Gamelan, tambur, dan slompret. Kemudian pada VIII sinom no 32 halaman 75, mengungkap instrumen tambur yang mengiringi barisan tentara kulit putih. Pada Pupuh X Kinanthi nomor 2 halaman 93 menyebut instrumenn Tambur dan Salompret. Pupuh XI Gambuh nomor 2 halaman 98 menyebut Salompret dan tambur. Pupuh XV Dandanggula nomor 25 halaman 134 menyebut kata tambur. Pupuh XVII Dangdanggula nomor 14 halaman 145 menyebut kata Tambur dan gamelan yang berbunyi. Kemudian pada pupuh XIX Gambuh nomor 5 halaman 157 menyebutkan gemuruh suara prajurit dengan bunyi gamelan menggunakan gending Kodok Ngorek dengan tepukan kendang.

Babad Lombok Babad Lombok terdiri dari 1221 pupuh yang berisi tentang asal mula orang sasak di Lombok dan perjalanan sejarahnya sampai mendirikan kerajaan. Kemudian penyebaran Islam di Lombok dan terakhir yaitu jatuhnya kerajaan Selaparang ke tangan raja Bali. Merupakan hasil transliterasi dari koleksi G. Parman oleh Ida Putu Mregig yang selesai pada hari Sabtu pahing tanggal 9 bulan ke 8 pada saka 1894 (1972 M). Dapat diketahui bahwa tambur dipergunakan dalam perayaan. Adapun pupuh yang mengandung kata tambur adalah nomor 239, 246, 252, dan 392. Pada pupuh nomor 239 terungkap seperti berikut. Dan tinambuh gamelaniyahasrih, lan serame, redep lan bilola, tan sipi-sipi ramene, hana hamungkur tambur hana surang sareng lan beri. Artinya:
Maka ditabuhlah sang gamelan, dan serame (serunai), rebab, dan biola, tak terkatakan ramainya, ada memikul tambur, ada bersorak sama gong bheri (Mintosih, 1999: 106).

Selanjutnya pada pupuh nomor 246 berbunyi: Ya hamiyos raja lanang histri, wus sami napak, dening bedil tumbak, gong beri tinabuh hage, tandak ronggeng lan tambur, tinimbalan surak lan bedil, kadi hombak segara, bedil halun-halun, tan sipi ramening kena ya. Artinya: Lalu Keluar Raja Laki-laki Wanita, sudah disambut oleh pasukan bedil tombak, gong bheri-pun ditabuh, tandak, ronggeng, dan tambur, bersahut sorak dan bedil, seperti ombak lautan, bedil bertalu-talu, tak terkatakan ramainya kenduri (Mintosih, 1999:).

Kemudian pada pupuh nomor 252 tersurat: Sang Nata tumedak, dening jampana juline, lanang wadon sinukul, maring kadaton suri, hingiring dening bala, surak gong tinambuh, bedil tambur gong gamelan. Artinya: sang raja naik, ke Jaumpana Jolinya, laki-laki wanita memikul, ke dalam puri, diiringi oleh rakyat, sorak dan gong yang ditabuh bedil tambur gamelan, (Mintosih, 1999:). Terakhir pada pupuh nomor 392 yang berbunyi: Tandak joget tambur hangrak, artinya: Tandak joget tambur gemuruh, (Mintosih, 1999:). Berdasarkan pada pupuh 392 dan 246, penulis menduga bahwa kata tandak, joged, tambur dan kata tandak, ronggeng, tambur, yang dimaksud dalam pupuh di atas jelas menunjukan kesenian Kecimol yang sangat digemari di Lombok. Apakah juga kata tambur yang dimaksud pada pupuh 239 saat ini dapat dipastikan seperti gambar 4.28 seperti di atas walaupun tentunya perlu penelitian lebih lanjut lagi. Kemudian terjadi kembali penerjemahan nama instrumen yang bukan pada instrumen yang berkembang pada daerahnya dipergunakan oleh penerjemah seperti serame (serunai), dan gong (gong bheri).

\section{Kata Ketug dalam Kakawin}

Diambilnya nama Ketug Bumi dari lontar Prakempa dan Aji Gurnita, mengisyaratkan bahwa nama ini ada pula dalam naskah kesusastraan Jawa kuno. Hal ini memenag terbukti seperti dalam kakawin Bharatayudha (Santosa, 2016) dan Sumanasantaka (Santosa, 2018), kata ketug diartikan sebagai menggelegar seperti gempa.

\section{Kakawin Bharatayudha}

Kata ketug terdapat dalam Pupuh X nomor 9 yang berbunyi sebagai berikut.

Ri sampunika mangkana nda maperang maso sahasa, Humung swaranikang gajah kuda lawan gubar mwang surak, Samanta $n$ atighurnniteng langit awuntwani dik widik, Gumeter i lemahnikang ranna-sabha ketugnyaselur (Wirjosuparto, 1968: 74). 
Artinya:

Kemudian mereka itu dengan gagahnya bersama-sama maju ke medan pertempuran. Suara gajah, kuda, gong dan teriakan manusia yang bertubi-tubi tidak ada putus-putusnya memenuhi angkasa sampai ke sepuluh jurusan. Tanah di dalam medan pertempuran itu menjadi getar dan terus menerus menjadi menggempa (Wirjosuparto, 1968: 211).

\section{Kakawin Sumanasantaka}

Penulis menemukan istilah karawitan yang tersurat dalam 27 syair kakawin Sumanasāntaka seperti berikut. Pupuh IX 1 (Sundari, ketug), pupuh XXV 4 (padahi, tabeh-tabehan, ketug, gubar, ghanta), pupuh CXLIII 7 (padahi, gong, ketug), pupuh CXLV 10 (ketug, gubar, garantung), pupuh CXLIX 29 (ketug, gong, gumecik, galempong), pupuh CLI 5 (ketug, gubar).

Pada pupuh IX nomor 1 Jagadnatha, berbunyi seperti berikut.

Huwus pranata bhakti tan pasaranasraya mati lumah ing pamancanan

Humung tangis $i$ sundari nikang alas hinariwuwu ni sabda ning gagung

Rereb kusumasari tan papegatan ketug $i$ tedun ing ertaling jurang

Lung ing gadung angindracapa humadang hawana nika madadya manusa

Artinya:

Setelah menghaturkan sembah, tanpa lindungan atau naungan, dia mati dan terbaring di tempat penggodaan. Capung menangis meraung-raung di hutan dan dilipur suara katak. Selubung serbuk sari tak terberai, juga gemuruh air terjun yang terjun ke jurang. Tunas sulur gadung berbentuk pelangi yang berdiri menunggu akan menjadi jalannya untuk menjelma manusia (Worsley, 2014:).

Pada pupuh 25 nomor 4 Abhikrti yang berbunyi: Ri lampah ira ghurnita ng padahi pangharep ira kumisik mangertali tiba

Saru swara nikabarung binarungan tabe-tabehan agenturan kadi gereh

Humandaru tiba gubar kumetug asring aniru ketug ing hudan wahu dawuh

Arum uni ghanta ning liman angungkang asahuran $i$ panghrik ing kuda bisir (Worsley, 2014: 134).

Artinya:

Saat mereka berangkat, tambur kerucut di depan menggelegar seperti bunyi air ditergen, Ditabuh berbarengan, bunyinya hingar bingar dan disertai tatabuhan, bergemuruh seperti guntur. Gong gubar, bagai guguran bola api, bertalu-talu seperti derai hujan. Bunyi lonceng yang dikenakan oleh gajah begitu memikat ketika berkeloneng menyahut ringkik dan

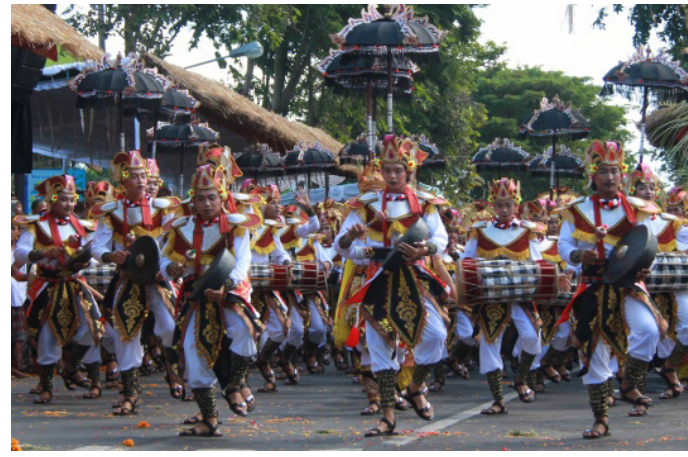

Gambar 4. Pentas Gamelan Ketug Bumi pada PKB ke34, 2016

(Sumber: Koleksi Unit Kearsipan ISI Denpasar pada 2016)

dengus kuda (Worsley, 2014: 135).

Kemudian pada pupuh 143 nomor 7 Dodhakawrtta berbunyi:

Salwir ikang padahing nagarasrang, Ramya tekapnya hanan sinameni, Len masarag makapanghada gongnya, Lwir ketug ing lewu dennya gumeter (Worsley, 2014: 384).

Artinya:

Segala macam genderang kerucut di ibukota ditabuh bertalu-talu, Bunyinya meriah diiringi sebagian orang, Sementara sebagian yang lainnya penuh semangat menopang genderang yang berukuran besar, Genderang menggelegar keras bagai halilintar menyambar-nyambar (Worsley, 2014: 385).

Pupuh 145 nomor 10 Jagadnatha tersurat:

I sampun ira munggah ing ratha tumut nrpawaraduhita hane wuri

Pasanggha ni surak watek raghusutamaji talinga nikang wwang angrengo

Linud $i$ ketug ing gubar saha garantung uni nika karengw anglw-alo

Ikang wwang apeken-peken gumuruh awreg inawaran i duta ning musuh (Worsley, 2014: 394).

Artinya:

Setelah Pangeran menaiki kereta perang, sang putri mengikuti. Deru teriakan bala tentara memekakan telinga. Demikian pula gelegar gong gubar dan garantung. Orang-orang yang bedagang di pasar kalang-kabut, dikacau mata-mata musuh. (Worsley, 2014: 395).

Kemudian pada pupuh 149 nomor 29 Basantatilaka berbunyi:

Na ling nika tucapa sabda ri de nikaprang Pyak byur kepuk ketelebuk kedepek ketug tog Cenghas tehaptehap aduh gedebeg dehak syok Carcab lebik bek adu gong gumecik gelempong (Worsley, 2014: 416). 


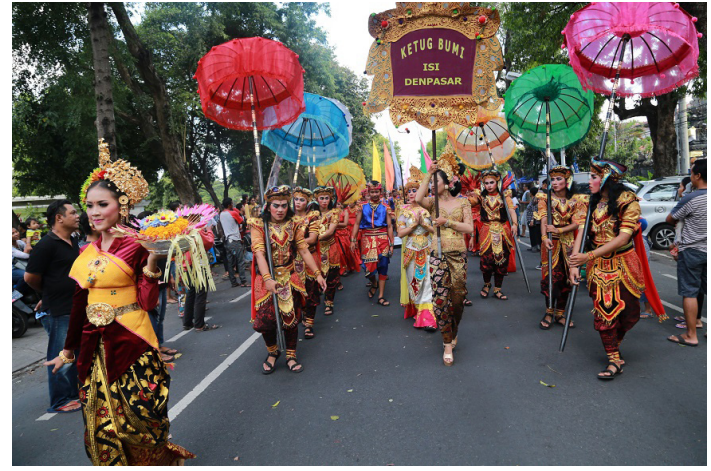

Gambar 5. Pentas Gamelan Ketug Bumi 2018 (Sumber: Koleksi Unit Kearsipan ISI Denpasar pada 2018)

Artinya:

Begitulah ujar mereka. Kami sekarang akan menyuarakan hiruk pikuk pertempuran, Pyak byur kepuk ketelebuk kedepek gedebeg dehak syok, Ceng has tehap-tehap aduh gedebeg dehak syok, Carcab lebik bek adu gong gumicik gelempong (Worsley, 2014: 417).

Terakhir pada pupuh 151 nomor 5 Jagaddhita yang berbunyi:

Mangso sahasa tan surud sang Anupadhipati manah ira $n$ waning rana, Panghrik ning kuda len grit ing ratha karengw aselur $i$ hiringan hane harep, $P a-$ krak ning balasanggha manggyat angasut ei bala sang Aja wani kambuhan, Teg tok lwir garudadahem ketug ikang gubar asahuran apratidhawani (Worsley, 2014: 418).

Artinya:

Raja Anupa, pantang mundur, mendesak maju dengan sengit karena ia pemberani di medan laga. Ringkik kuda dan derit kereta terdengar terus di sayap-sayap maupun di depan. Pekik pasukannya yang menyerang mengejutkan tentara Aja, tapi mereka menahan serangan dengan berani. Gongngng gungngng! Gelegar gong gubar yang menggema bersahut-sahutan terdengar seperti elang batuk (Worsley, 2014: 419).

Berdasarkan uraian karya kesusatraan kuna, kata ketug menunjukan tentang suara yang menggelegar dan dihasilkan oleh instrumen musik yang wujudnya besar pula.

\section{SIMPULAN}

Kreativitas seni Pertunjukan Bali (gamelan Bali) tidaklah lekang oleh perubahan zaman, kreativitas berjalan menyesuaikan zaman dari masa lampau hingga masa kini, seiring dengan perubahan fungsi dan bentuk gamelan itu sendiri. Gamelan telah berevolusi sesuai dengan perkembangan pikiran manusia dalam mengejawantahkannya dalam kehidupan manusia. Begitu pula dengan gamelan Ketug Bumi pada masa sekarang telah berkembang dan berevolusi menyesuaikan tempat, keadaan dan situasi dimana mrëdangga, teteg, keteg, bedug, tambur atau kendang beleq itu berada yang difungsikan oleh masyarakat pendukungnya. Oleh karenanya, gamelan Ketug Bumi adalah hasil oleh kreativitas manusia Bali yang berdasarkan kehidupan dari berbagai peristiwa masa lampau yang dilaluinya.

Istilah tambur sebenarnya berasal dari Perancis yang penyebarannya di Indonesia tidak lepas dari peran Belanda ketika menduduki Nusantara. Oleh karena itu, panggilan genderang atau gendang besar dengan menggunakan istilah tambur terjadi secara perlahan karena kontak yang cukup lama antara penduduk yang memiliki tradisi pemanfaatan genderang dengan pihak VOC yang mempunyai genderang dengan menggunakan nama tambur. Kata tambur tersebar dalam karya kesusastraan yang berusia muda, disebabkan oleh begitu luasnya pengaruh Belanda dalam menyebutkan gendang besar. Bahkan tambur sudah diadopsi dalam gamelan Jawa dan Bali sebagai sebuah bentuk simbolik keagungan keraton, baik sebagai pengiring baris pada prosesi prajurit maupun dalam seni pertunjukan lainnya.

\section{DAFTAR RUJUKAN}

Aryasa, I. W. (1976). Perkembangan Seni Karawitan di Bali. Denpasar: Proyek Sasana Budaya Bali.

Bandem, I. M. (1986). Prakempa, Sebuah Lontar Gamelan Bali (Trans.). Denpasar: ASTI Denpasar.

Garraghan, S. J. G. (1957). A Guide to Historical Method,. (J. Delanglez, Ed.). New York: Fordham University Press, East Fordham Road, Fourth Printing.

Gootchlak, L. terjemahan N. N. (1975). Mengerti Sejarah (Pengantar Metode Sejarah), Terjemahan Nugroho Notosusanto. Jakarta: Universitas Indonesia.

Herlina, N. (2014). Metode Sejarah (Revisi). Bandung: Yayasan Masyarakat Sejarawan Indonesia Cabang Jawa Barat.

Kunst, J. (1968). Hindu Javanese Musical Instruments. The Hauge, Holand: Martinus Nijhoff.

Kuntowijoyo. (2003). Metodologi Sejarah. Yogyakarta: Diterbitkan atas kerjasama dengan Jurusan Sejarah Fakultas Ilmu Budaya Universitas Gadjah Mada, PT. Tiara Wacana Yogya. 
Lukman, A. (1996). Kamus Besar Bahasa Indonesia. Jakarta: Departeman Pendidikan dan Kebudayaan, Balai Pustaka.

Mintosih, S. (1999). Pengkajian Nilai Budaya Naskaha Babad Lombok Jilid 1. Jakarta: Departeman Pendidikan dan Kebudayaan, Direktorat Jenderal Kebudayaan.

Sachs, C. (1940). The History of Musical Instruments. New York: W.W. Norton \& Company Inc. Publisher. Santosa, Hendra., Dyah Kustiyanti., K. S. (2016). TRACES OF MUSICAL INSTRUMENTS IN KAKAWIN BHARATAYUDHA. E-Journal of Cultural Studies, 9. Retrieved from https://ojs.unud.ac.id/ index.php/ecs/article/view/35695

Santosa, Hendra., D. K. (2018). Mrědangga: Sebuah Penelusuran Awal Tentang Gamelan Perang di Bali. Kalangwan, 4(1), 16-25. Retrieved from http:// jurnal.isi-dps.ac.id/index.php/kalangwan/article/ view/281

Santosa, H., Kustiyanti, D., Sudirga, I. K., Karawitan, J., \& Tari, J. (2018). Jejak Karawitan dalam Kakawin Sumanasantaka. Panggung, 28(1), 48-61. Retrieved from https://jurnal.isbi.ac.id/index.php/panggung/article/view/272

Wirjosuparto, R. (1968). Kakawin Bharata-Yudha. Djakarta: Penerbit Bharata.

Worsley, P. (2014). Kakawin Sumanasantaka, Mati Karena Bunga Sumanasa, Karya Mpu Monaguna., Kajian sebuah puisi epik Jawa Kuna (Terjemahan). Jakarta: Ecole Francaise d'Extreme-Orient Koninklijk Instituut voor Tall, Land en Volkenkunde, Yayasan Obor Indonesia.

Yudhi Irawan, D. (2008). Suntingan dan Terjemahan Babad Majapahit Jilid I, Kencana Wungu Naik Tahta (Cetakan 1). Jakarta: Perpustakaan Nasional RI. 